\title{
Web Radio: educational nursing care technology addressing cyberbullying students' statements
}

\author{
Web Rádio: tecnologia de cuidado educativo de enfermagem abordando os dizeres de escolares sobre cyberbullying
}

Radio Web: tecnología educativa de cuidado de enfermería que aborda los dichos de los estudiantes de ciberacoso

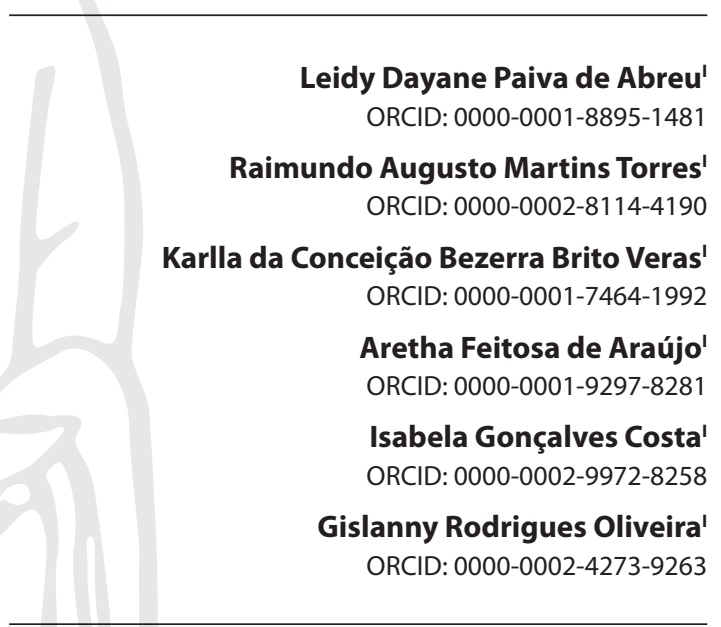

'Universidade Estadual do Ceará. Fortaleza, Ceará, Brazil.

How to cite this article:

Abreu LDP, Torres RAM, Veras KCBB, Araújo AF, Costa IG, Oliveira GR. Web Radio: educational nursing care technology addressing cyberbullying students' statements. Rev Bras Enferm. 2020;73(4):e20180872. doi: http://dx.doi.org/10.1590/0034-7167-2018-0872

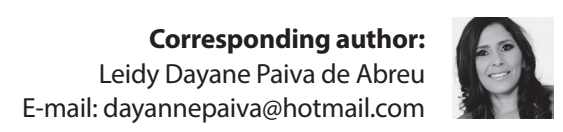

EDITOR IN CHIEF: Antonio José de Almeida Filho ASSOCIATE EDITOR: Fátima Helena Espírito Santo

Submission: 02-12-2019

Approval: 09-08-2019

\begin{abstract}
Objectives: to understand, from the vocabulary universe of young students, the knowledge and statements on cyberbullying via Web Radio Associação de Jovens de Irajá. Methods: a qualitative research. Students'speech questions were used on the web radio's message board and on the station's social networks; 35 students participated. The analysis was based on Paulo Freire's Culture Circle and Thematic Analysis. Results: the following categories emerged: "Cyberbullying: Reading the World Youth School", which describes the vocabulary universe of youths: social networks, bullying, internet, cyberbullying, violence, fakes and anonymity; and "Is Cyberbullying a Joke or Virtual Violence?", which points to the health consequences, therapeutic alternatives of treatment and punitive laws. Final Considerations: nursing educational care with schoolchildren via web radio brought contributions on cyberbullying, since the youths adopted reflective postures in the face of the problem.

Descriptors: Students; Nursing; Technology; Bullying; Care.
\end{abstract}

\section{RESUMO}

Objetivos compreender, a partir do universo vocabular dos(as) jovens escolares, os saberes e dizeres sobre cyberbullying via Web Rádio Associação de Jovens de Irajá. Métodos: pesquisa qualitativa. Utilizou-se perguntas-discursos dos escolares, feitas no mural de recados da web rádio e nas redes sociais da emissora, com participação de 35 estudantes. A análise foi fundamentada no Círculo de Cultura de Freire e Análise Temática. Resultados: emergiram as categorias: "Cyberbullying: leitura de mundo da juventude escolar", que descreve universo vocabular das juventudes: redes sociais, bullying, internet, cyberbullying, violência, fakes e anonimato; e "O cyberbullying é uma brincadeira ou violência virtual?", que aponta as consequências para a saúde, as alternativas terapêuticas de tratamento e leis punitivas. Considerações Finais: o cuidado educativo de enfermagem junto a escolares via web rádio trouxe contribuições sobre o cyberbullying, visto que as juventudes adotaram posturas reflexivas diante da problemática.

Descritores: Estudantes; Enfermagem; Tecnologia; Bullying; Cuidado.

\section{RESUMEN}

Objetivos: comprender, desde el universo de vocabulario de los jóvenes estudiantes, el conocimiento y los dichos sobre el ciberacoso a través de Web Radio Associação de Jovens de Irajá. Métodos: Investigación cualitativa. Se utilizaron las preguntas del discurso de los estudiantes, realizadas en el tablero de mensajes de la radio web y en las redes sociales de la estación, con la participación de 35 estudiantes. El análisis se basó en el Círculo de cultura y análisis temático de Paulo Freire. Resultados: surgieron las siguientes categorías: "Cyberbullying: leer el mundo de la juventud escolar", que describe el universo de vocabulario de los jóvenes: redes sociales, bullying, internet, cyberbullying, violencia, falsificaciones y anonimato; $y$ " ¿Es el ciberacoso una broma o una violencia virtual?", que señala las consecuencias para la salud, las alternativas terapéuticas para el tratamiento y las leyes punitivas. Consideraciones Finales: el cuidado educativo de enfermería con los escolares a través de la radio web aportó contribuciones sobre el ciberacoso, ya que los jóvenes adoptaron posturas reflexivas ante el problema.

Descriptores: Estudiantes; Enfermería; Tecnología; Intimidación Cuidado. 


\section{INTRODUCTION}

Without claiming to find a definitive answer or to offer a truth, it was preferred for this research to use the terminology young and youth (s) rather than adolescent (s). Such terminologies may not strictly refer to a specific age range or a series of biologically recognized behaviors. The choice of the term youth stems from the fact that this audience is immersed in diverse cultural settings. They produce their lives mediated by their daily experiences and experiences in groups and other territories ${ }^{(1)}$.

One of the greatest problems faced by youths is the violence in everyday schools. In addition to physical aggression, a new, subtler and cruel practice of violence emerges, bullying, which has been occupying a prominent space in this environment. The word bullying comes from the English language and refers to bully, which is understood to mean "bully", one who constantly mistreats or violates other people for trivial reasons. It is precisely this act of mistreating or violating the other in a systematic and repetitive manner that is called "bullying". Cyberbullying, then, is when aggression occurs through virtual media such as social networks, the telephone, and other virtual media( ${ }^{(2)}$.

Cyberbullying is when they use communication technologies to denigrate, threaten, humiliate, or commit any other malicious act to third parties. Cyberbullying affects victims'coexistence and mental health as well as undermining citizens' fundamental rights. It is of concern as it has been considered as one of the most dangerous and treacherous forms of violence. Although cyberbullying is not physical aggression, and is therefore commonly viewed as less harmful, studies have shown that the consequences are as severe or as serious as physical bullying ${ }^{(3)}$.

The abuses suffered by the victims of virtual bullying are mostly psychological in nature. However, there are extreme cases where they can become physical. Threats of death, physical assault, and posting of victims' personal information are some of the most violent means of cyberbullying. They put the victim at risk and constant apprehension about the possibility of an attack on their life. Most of the attacks happen to young people at school. The attacks on cyberbullying victims are usually directed at personal characteristics and made in the public environment, denigrating the public image and affecting their self-esteem. Abuse is constant and can take on huge proportions as the dynamics of the online world are huge and often unmanageable ${ }^{(2-4)}$.

Most youth use the internet as a tool to produce and post their ideas and generate various ways of interaction. However, some uses, such as bullying, can cause damage. Therefore, schools were chosen as a focus on educational nursing care, using web radio information technology to understand cyberbullying. Schools are the most conducive environments for the development of reflective critical thinking, being the main places where the systematized teaching-learning process occurs, outside the family education.

Nursing educational care with youths is highlighted, replacing the merely campaigning practices that are characterized by the centralized, vertical and unidirectional hegemonic model. In this sense, the educational care mediated by communication and information has been built in the context of nursing science over time, under the meaning of improvement of care practice. To practice this practice, professionals need to understand their multidimensionalities, changing character and potentiality of the available tools. This happens in the case of digital tools, as well as the scenario permeated by the production of this type of care, as it aims at their quality development ${ }^{(5)}$.

From this perspective, the use of these technologies was combined with education and health, thus creating the Web Radio AJIR (Irajá Youth Association). It is a digital broadcaster that aims to spread information and knowledge through the digital medium. It acts in communication and health education through the transmission of a diversified programming with themes about collective health for young students, as well as being based on important references such as Paulo Freire ${ }^{(6-7)}$.

Web radio is a tool in the teaching-learning process that encourages youth participation, providing dialogues, dynamic learning, information, communication and interaction, connecting various places, cities and countries due to the size made possible by the internet. One of the programs aired on this channel is "In tune with health (S@S)". It was developed in a studio room at Universidade Estadual do Ceará - UECE, state of Fortaleza, city of Ceará, with weekly live and/or recorded programs, available on the Radio AJIR website for later consultation over the internet.

Therefore, the research presented the following question: what are the knowledge and sayings of young people from public schools about cyberbullying? It is believed that the "In tune with health (S@S)" program is an educational care strategy that enables participants to dialogue with others about healthrelated problems in schools so as to constitute comprehensive, constructive and democratic spaces.

\section{OBJECTIVES}

To understand, from the vocabulary universe of young students, the knowledge and sayings about cyberbullying via Web Radio AJIR.

\section{METHODS}

\section{Ethical aspects}

The survey met Resolution $466 / 12$ as part of a larger survey called"Uso da web rádio na formação e no cuidado em saúde: experimentando estratégias de comunicação e educação em saúde com as juventudes". Students and parents or legal guardians signed a Free and Informed consent form. The research was approved by the UECE's Research Ethics Committee, ensuring confidentiality and anonymity.

\section{Theoretical-methodological framework}

The theoretical framework used was the Vocabulary Universe, first phase of Paulo Freire's Culture Circle ${ }^{(8)}$, structured in: Discovery of the Vocabulary Universe; Generating Words, Thematization and Problematization.

From the Discovery of the Vocabulary Universe, Generating Words are extracted. Therefore, the Vocabulary Universe is the relation of the words of current usage, understood as representative of the groups' ways of life or of the territory where they 
will work (reality study), allowing the closer contact with the language, singularities in the ways of speaking of the language. people and life experiences on the place ${ }^{(7-9)}$. Thematization is the process by which themes and generating words are codified and decoded, seeking the meaning of lived and social. This enables the expansion of knowledge and understanding of people about their own reality, from the perspective of critically intervening on it. Problematization is a decisive moment of the proposal and seeks to overcome the naive view by a critical perspective, capable of transforming the lived context ${ }^{(8)}$.

Paulo Freire conducted research on building knowledge of local reality with the aim of engaging with literacy work in the communities. Then, works were produced that founded and conceptualized the Culture Circles. This first pedagogical step of the method was named by Freire as "survey of the vocabulary universe" (in Education as Practice of Freedom) ${ }^{(8)}$.

\section{Type of study}

The study consisted of a research with qualitative approach of exploratory-descriptive type ${ }^{(10)}$.

\section{Study setting}

The research was carried out in Web Radio AJIR cyberspace from the program "Em sintonia com a saúde (S@S)" (In tune with health (S@S)). It was also held in the royal area of the state of vocational education school of the city of Soutral, state of Ceará, May 2018, through a discussion with schools about cyberbullying. The program is broadcast on Wednesdays via the digital web radio channel from $4 \mathrm{pm}$ to $5 \mathrm{pm}$ live at the UECE studio, Fortaleza, to five cities (Fortaleza, Juazeiro do Norte, Ubajara, São Benedito and Sobral).

The digital channel's schedule is diverse, presenting interactive content for the youth public of schools. Weekly, dialogues on topics related to health education. The moments are facilitated by the nursing fellows and students of the Graduate Program in Clinical Care in Nursing and Health of UECE ${ }^{(1)}$."In tune with health (S@S)" demands are suggested by school territories registered in the program. Web radio receives the proposals, assesses and selects them, then establishes its annual schedule. Invited experts from various areas of health and education, who talk about sexuality, teenage pregnancy, peace culture, HIV/AIDS, sexually transmitted infections (STI), violence, gender, bullying, cyberbullying, among others.

The selection met the following inclusion criteria: students enrolled in the program who participated in the cyberbullying theme. In all, there were 35 young students from the $1^{\text {st }}$ scientific year, aged 14 to 15 years, from a school in Sobral. An expert nurse invited to the interview also participated. It is noteworthy that the research was conducted in the school territory where the researcher is a pedagogical articulator, having direct contact with students. Therefore, data from students listening from other schools and other municipalities registered in the program were not computed.

The activities start with an anchor question, presented by the program announcer: "What do you understand by cyberbullying?".
Then, in dialogic interactions, "questions-speech" are performed by the students, where they are encouraged to send questions/ comments via web radio. These questions are discursive productions of youths in interaction, which are used as a source of empirical material ${ }^{(10)}$.

Discussion was measured by the vocabulary universe of students, which are repeated, through a collective discovery, coming from the world through the word. Thematization is carried out, providing a more effective involvement and bond between researcher and youth, in addition to favoring positive results from the use of web radio.

During the program, there is a team of four people in the studio for the production of the program: 1) "announcer", with the functions of interviewing the guest and mediating the program; 2) Cameraman, with the function of recording with the digital camera the program, is also responsible for the live broadcast via webcam; 3) "virtual mediator", whose function is to interact and communicate with the public, generating mediation between them and the interviewee, by appropriating the comments and questions from schoolchildren, obtained on the website and on the social networks; 4) circulating, with the function of assisting the operation of the program and solving pending issues that may arise during transmission ${ }^{(11)}$. In school territories, teachers and nursing students are part of the pedagogical coordination and mediation, receiving the students for the interaction in the classroom program. Field mediators participate and articulate the web radio project. They are collaborators in this moment of communicative interaction and facilitate the sending of questions and/or comments from young people.

The audience's interactive process with the guest and speaker takes place online through the board of messages from the broadcaster's website and/or Facebook/WhatsApp. Through the mediator who receives these infovias, individualized questions and comments from the youth are passed on to the speaker and discussed live with the nurses or other invited health professionals, specialists in the subject ${ }^{(1)}$. During the program, everyone watches the broadcast at the collective via the data show, with access to peer questions and discussions.

In the production of the program, images are shot on the channel's website through Web TV, allowing the eye contact permeated by non-verbal language. In addition, there is the verbal, written language, mediated by the interaction texts of the program's production team with netizens; produced by the speeches of the speaker and the guest ${ }^{(11)}$.

\section{Collection and organization of data}

Data were collected from youth responses and speech questions, left on the radio's web board, Facebook and WhatsApp. All material, which translates as textual construction shared by writing, speech and aesthetic constructs, i.e., hypertext, is archived on the computers belonging to the program. The pseudonyms Young 1, Young 2... Young 35 were used, as well as a field diary in loco, in order to describe the mobilization, interaction and vocabulary universe in which the students are inserted. It was specified in the speech questions which were from the board of messages and social media. 
After the anchor question was launched, the dialogue began with the interviewee, a nurse specialist in the subject. During this dialogue, a brief explanation of key points that stood out in the vocabulary universe of youth was developed, considering the generating words of this universe: social networks (12 times), bullying (11), internet (8), cyberbullying (6), violence (3), fakes (2), and anonymity (2).

\section{Data analysis}

The first stage of the investigation of "generative themes" is through dialogue via web radio. The fundamental object is to study the perception and core of contradiction of individuals in the area. These contradictions are no more than "limit situations." This set of contradictions is not enough to structure the programmatic content of educational action ${ }^{(8)}$.

The next phase of the investigation begins when the researchers, from the data they have gathered, come to the apprehension of limit situations. As a team, they chose some of these situations or contradictions to be codified. Once the codings are prepared, the researchers begin the third phase with the decoding of the elaborated material. In this, they return to the area to inaugurate the decoder dialogs. Once this is done, the fourth phase begins, when the investigators, having finished the decoding in the circles, begin the systematic study of their findings. At first the researchers listened to the recordings and the decodes.

The description of the results included records of complete speech, ordered by narration and discussion. This allowed analysis based on the Paulo Freire method assumptions ${ }^{(7)}$ and Thematic Analysis $^{(12)}$. In the Vocabulary Universe ${ }^{(8)}$, the dialectical meaning prevails in its extension. The stage intertwines and blends so that the teaching-learning process happens completely and meaningfully for both the learner and the teacher. The Thematic Analysis technique ${ }^{(12)}$ consists in discovering the nuclei of meaning that make up a communication. For an analysis of meanings, the presence of certain themes denotes relevance structures, reference values, and behavior models present or underlying in the discourse.

\section{RESULTS}

The research highlights the privileged locus of communicationdiscussion based on dialogue and educational nursing care outside health institutions, in other spaces, such as schools; in the experiences of the actor-subjects in their word universes; in the theoretical production of health education; and in listening. This is guided by the desire of each and every one to learn the speech of the other and the other, problematizing them and problematizing with regard to cyberbullying.

\section{Cyberbullying: Reading the World Youth School}

The activities started with an anchor question related to the theme, made by the speaker. Through this reading of the world, we sought to dive into the universe of youth. The questions revealed below represent the population in question, which guided the discussion, and those that enhanced dialogue optimization were chosen.
Chart 1 - Answers to the anchor question during the program "In tune with health (S@S)", taken from Board of messages, Facebook and WhatsApp, via Web Radio AJIR, Sobral, Ceará, Brazil, 2018

\section{Anchor Question: “What do you understand by cyberbullying?”}

Young 1: Cyberbullying is a form of verbal violence, prejudice, carried out in social networks, i.e., in the virtual environment. (Board of messages)

Young 2: Cyberbullying is a different way of bullying, that is, through social networks. (WhatsApp)

Young 3: It means a kind of bullying through social networks, where people create fakes to attack the target person with a lot of hatred. (Board of messages)

Young 4: It means bullying over the internet. (WhatsApp)

Young 5: Bullying on social networks, i.e., the internet. (Board of messages)

Young 6: It's the means of bullying on the internet. I read this on a website. (Facebook)

Young 5: Cyberbullying is bullying practiced on social networks. (Board of messages)

Young 8: It's the practice of bullying people over the internet. (WhatsApp)

Young 9: Cyberbullying is a different way of doing it, that is, through social networks. (Facebook)

Young 10: These are assaults, verbal swearing over the internet, violence that humiliates and ridicules the victim. (Facebook)

Young 11: Cyberbullying is a type of aggression on the Internet, which can have major impacts, the most used form is verbal aggression. (WhatsApp)

Young 12: I'm very curious about the topic and saw on the net that is bullying on social networks. (Facebook)

Young 13: It's virtual bullying by attackers who use social anonymity to offend and abuse people in many ways. (WhatsApp)

Young 14: A certain individual who suffers from some kind of social media violence. (Facebook)

Young 15: It's a kind of bullying, virtually all of which occurs on social networks. (Board of messages)

Young 16: Cyberbullying is bullying practiced via the Internet, social networks, posts and messages. (WhatsApp)

Young 17: It is a virtual bullying that can be practiced by anonymity or not by the offender. (WhatsApp)

Young 18: Uses virtual space to broker and harass a schoolmate or teacher or even slander the lies, destroying one's life, potentially leading to serious psychological problems of socialization, and even taking one's life. (Facebook)

Source: Board of messages from the Web Radio's website, WhatsApp, Facebook, 2018.

Thus, after the question was launched, the dialogue led by an expert nurse began. In this phase, a brief explanation is made with some key points on the subject. It is understood that nurses, when educating in health, need to transcend the subject, understand their intimacy to. With this, they can work on the indispensable relationships to care effectiveness. It is possible to observe that AJIR Web Radio is a strong enhancer of an educational process. The Internet becomes a mechanism for discussion, increasing curiosity and knowledge exchange. 


\section{Is Cyberbullying a Joke or Virtual Violence?}

Youth participating in the program were encouraged to submit "speech questions". It allows the approximation between health professionals and students in a more informal relationship, but loaded with learning, approximation with language and culture.

Of the 35 students, 16 asked questions about the theme. Most of them are insecure and afraid to ask questions and comment. Because interaction happens in the classroom, most questions are questions from a collective: some classmates ask individual questions. Discussion happens to everyone via digital media. During the dialogue, some are euphoric, others shy when asking the questions, generating behavioral instability. However, the construction of the bond between participants and the program's mediator in schools enabled the active participation of these subjects, with control of the situation.

From the questions, it was possible to perceive a vocabulary universe surrounded by doubts regarding cyberbullying: help, treatment, offender, aggression, causes, prevention, laws, combat, psychological problems, and disease. The discussion is associated with the creation of a space for dialogue, in which participants have doubts about the consequences of cyberbullying, psychological problems and illness of victims, as seen in the following statements:

Can bullying make a person sick? Sick to the point of treatment? (Young 1, WhatsApp)

Although there is much connected and informed about the consequences of cyberbullying, why is it still so common? (Young 04, Facebook)

What are the most serious consequences of cyberbullying for its victims? (Young 10, WhatsApp)

What psychological problems may arise in victims? (Young 12, Board of messages)

Can bullying make a person sick? Sick to the point of internment, treatment, and killing yourself? (Young 14, Facebook)

The guest pointed out that cyberbullying causes disruptions in the lives of victims, with physical, psychological and social interaction symptoms, which can lead to extremes of stress, aggression, even suicide on the part of the victim. She pointed out that perpetrators have some disturbances in social and psychological relations, becoming a serious public health problem.

Youths presented questions and provocations about how to prevent themselves and about the forms of treatment to combat cyberbullying, observed in the speech questions.

How to work cyberbullying at school? (Young 3, Facebook)

How can [sic] cyberbullying prevention practices be done? (Young 5, WhatsApp)

How can we do to help the person who has gone through this? (Young 9, Board of messages)

What are the aggression prevention practices? (Young 11, WhatsApp)
What is the best way to combat this practice? (Young 15, Board of messages)

What steps can cyberbullying people take? (Young 16, Facebook)

How can schools help young people to fight cyberbullying, since schools are a place that can influence practice? (Young 7, WhatsApp)

The interviewee emphasized strategies such as observing conversations between friends, different behaviors, social isolation, excessive absences, unusual silence, and may indicate that the young person is being embarrassed or intimidated by peers. The interviewee also explained that preventive actions should not be punctual or concentrated in a special week devoted to the topic. He stressed that if they were connected with the possible offender and offender, they would not fail to pass the case to school. Dialogue can resolve much of the conflict. There is responsibility of schools in cases involving students: even if the virtual attacks were made outside this space, it is necessary to pass the problem to teachers and school management.

As for group learning, students showed a desire to learn subjects related to strategies that can help the offender and the offender, the main causes, as well as the abusive use of fake news; also showed interest in knowing if there are laws to combat this type of violence.

No mechanism has been created to identify the fakes that attack people? (Young 2, WhatsApp)

Is there a Brazilian law that characterizes bullying? (Young 6, Facebook)

What are the causes of the oppressor practicing cyberbullying? (Young 8, WhatsApp)

What must be done to help victims and offenders? (Young 13, Facebook)

The Antibullying Law in Brazil has been mentioned, emphasizing that the ideal is to avoid the punishment of offenders in other instances than schools, favoring mechanisms and instruments that promote dialogue, awareness, accountability and behavior change. It is possible to understand that young people see web radio as a way to clarify doubts that often go unnoticed in their daily lives. The timing has resulted in a better understanding of how to intervene in cyberbullying cases. In this space, students were also encouraged to develop their critical thinking, enhancing their abilities.

\section{DISCUSSION}

Culture Circle is a space where dialogically is taught and learned. In it, there are no spaces for knowledge transfer, but for the construction of knowledge. School youth have much to contribute to the group on cyberbullying issues. They are discussion triggers and may involve all participants in these moments of dialogue and mutual enrichment ${ }^{(7)}$. Various types of violence are presented such as intimidation and humiliation among young people connected to the Internet, which extrapolate the school space. With $77 \%$ of the total population between 10 and 17 years old surfing the Internet, 
virtual environments have become territories of practices already known from behind the scenes such as bullying ${ }^{(13)}$.

Among online and offline worlds, $27 \%$ of children ages 9 to 17 say they have experienced situations where someone has acted offensive or upset them in the last 12 months. Of these cases, $15 \%$ happened on the Internet, with virtual bullying in the form of threats and the spread of slander. Of the electronic means used for cyberbullying, cell phones are the most common. In $2013,75.2 \%$ of the Brazilian population and $76.7 \%$ of 15 - to 17-year-olds had a mobile phone for personal use, which creates a large and conducive scenario for high cyberbullying rates ${ }^{(14)}$.

Research shows that students do not tell parents and teachers what they are suffering, especially in cases of cyberbullying; prefer tell to friends. Peer support networks are a way for students to get involved in the solution and feel welcomed by peers who identify with situations ${ }^{(3)}$. The audience may be silent, coauthor, collaborator; but, on the other hand, you may also learn to inhibit these actions. Young people need to be sensitized to take a stand on what is not legal and therefore should not be shared. Cyberbullying can reach a huge audience with sharing, regardless of where it started, the repercussion happens within the school, so it must be faced by it, involving the whole network of relationships: who does it, who gets it and who witnesses it ${ }^{(13)}$.

The anonymity guaranteed by the internet is responsible, in most cases, for the violence in the virtual space, computers, mobile phones, tablets, among other devices. Coupled with anonymity, the fact that technological devices are increasingly in the hands of young people contributes to this transition. Cyberbullying is still permanent, since when it is played online the information remains there indefinitely. It should be noted that when the young person watches silently or laughing, he or she is co-responsible for the action, which is characterized by aggression by peers and, necessarily, by an audience ${ }^{(4)}$.

Cyberbullying can reach far greater repercussions than traditional bullying. It occurs in a virtual, real-time space where free expression is allowed without social control, and exposed data cannot easily be removed after it falls on the network ${ }^{(5)}$. Given that the situation occurs virtually, sometimes within miles of the offender and the victim, a false sense of impunity for the offender is created. It is common, in the dark environment of the internet, the use of fictitious profiles by attackers to obtain information published on social networks and search for possible new victims. This type of aggression leaves the victim vulnerable and confused as to where the offense came from, as the offender can be anyone, from someone known to someone residing on another continent ${ }^{(13)}$.

Overall, when it comes to the physical symptoms of cyberbullying, perpetrators and victims usually present the same manifestations as sleep and attention disorders, headache, abdominal pain, and nausea. In addition to physical symptoms, attacks can lead to the appearance and/or increase of disturbing psychic disorders such as symptoms of depression, anxiety, decreased empathy, and suicidal thoughts on the part of the victims. However, perpetrators tend to increase aggression levels outside the virtual environment, making them more prone to miscellaneous violence, drug use and crime ${ }^{(14)}$.

Most victims have the same emotional reactions, including embarrassment and anger. The latter is a fairly common answer. In this whirlwind of exacerbated violence and feelings arose, there are also people who report not caring, showing a process of adaptive resilience that minimizes emotional damage ${ }^{(15)}$.

Even with students involved in the solution, combating cyberbullying is a work of the entire school community. Training teachers and other staff members to implement prevention activities and guiding them together to seek exit in problematic cases are essential actions. These situations call for a performance protocol that implies a change in the attitude of teachers in the way they introduce dialogue; in the way they show the victim the possibility of being angry; how to get the perpetrator to repair the problem he caused; and in the treatment given to mere bystanders. Therefore, serious training is needed for the school community to deal with the problem ${ }^{(2)}$

School should propose accountability not with the intention of merely punishing, but in order to repair the evil. Published information about victims should be removed from the air and, in cases of slander, should be denied, thus restoring respect and affected relationships. It is also possible to redirect the skills of young cyberbullying practitioners to more beneficial roles. The theme needs to be addressed as the focus of institutional and intersectoral project, with the construction of a permanent program to combat cyberbullying that is in the pedagogical political project of the institution. The point is to guide students to make responsible use of the networks. Therefore, each school must design its project according to its characteristics, which may also have the collaboration of the youths $s^{(3-13)}$.

Preventive actions need to be established at school and in health through intersectoriality, as cyberbullying is a public health problem. Therefore, nursing has been occupying the school space through educational care. It is necessary to maintain democratic spaces, promote conversation circles and moments so that students can participate in decisions, talk about problems they face in daily school life and how they feel, making their coexistence healthier ${ }^{(15)}$.

Nurses are involved in different contexts, including the school environment. As they are professionals who are closer to users most of the time, it is essential that they know how to identify and act on cyberbullying practices. Thus, they will be able to develop prevention activities and also to treat the students who practice or suffer from it ${ }^{(2)}$. For Freire ${ }^{(7)}$, it is necessary to build authentic knowledge (based on the Brazilian reality and giving answers to the problems experienced by the people) and organic (in close relationship with the lived reality, seeking to transform it). Hence the role of the nurse in educational care, in which awareness and knowledge built through the educational process would have the function of motivating and driving transformative actions in relation to the theme.

It is necessary to support the victim and support the health professionals in schools. In extreme cases, when schools cannot deal with the problem, it is recommended to pass it on to the family. Collectively, appropriate action should be taken within the legal framework, with the help of a lawyer specializing in digital law to ascertain the best course of action for each situation ${ }^{(6)}$. Even with all the advancement of the media and technology, there are doubts about crimes committed virtually. They are called "cybercrimes", which are nothing more than real-world crimes in a more advanced way, which often makes it difficult to identify the perpetrator. These cybercrimes can come from a variety of ways, and can happen as insult, discrimination, falsification of bank information or even access to intimate documents ${ }^{(3)}$. 
Anyone who commits any kind of crime on the internet can be punished. The Internet Civil Framework provides for accountability of agents, according to their attitudes. Law 13.185/15, also known as the Antibullying Law, institutes the Program to Combat Systematic Bullying (Programa de Combate à Intimidação Sistemática) and characterizes any act of physical or psychological intentional and repetitive violence ${ }^{(13-15)}$. It is necessary to demystify the idea that there are no consequences for actions among young people. Many people use fake profiles and make very heavy attacks, thinking they are protected by anonymity. However, it is possible to identify the IP of the author's computer. Once the person in charge is identified, the person can be prosecuted. In the case of children under 18, parents and legal guardians are penalized for their acts ${ }^{(4)}$.

The law includes bullying and cyberbullying and aims to provide psychological, social and legal assistance to both victims and perpetrators. It also promotes empathy and acidity, enabling teachers, pedagogical teams, parents and family members to implement discussion, prevention, guidance and solution actions and to disseminate education, awareness and information campaigns. However, it is a law that is still little known by society, especially victims, who sometimes feel embarrassed to seek legal means to combat this type of violence ${ }^{(14)}$.

Web radio is a resource that is part of the new arrangements for the implementation of actions aimed at health promotion in a more dialogical, interactive and rich dimension of new knowledge. This occurs through the surroundings of young people's daily life in school and in the community, surpassing the traditional model and moving towards the co-production of knowledge and autonomy of young people ${ }^{(11)}$.

\section{Study limitations}

Nursing involvement in combating this type of violence still occurs in a slow and timid manner. Although educational actions take place, they are still not comprehensive in this regard. It is pointed to the necessity of qualifications of nurses that make possible subject knowledge, creating, therefore, measures of identification and combat to this violence, in the teaching institutions and in other communities, where they act.

\section{Contributions to nursing, health or public policy}

The study contributes with arguments to problematize the line of attention to school youths through educational nursing care. They are based on the construction of actions to combat cyberbullying through web radio as an articulation of the subjects' social network. The comprehension of the problem is broadened and it is pointed to a necessary articulation of health care with care comprehensiveness for reception and care, in the intersectoral and interdisciplinary perspective, in order to a greater resolution of the problem. It is necessary to reflect on the role of nurses in schools, contributing to the reduction of cyberbullying and the establishment of a universal, comprehensive and equitable care. Health services and the health field can also use this study in formative processes to counter the institutionalized cyberbullying culture against young students.

\section{FINAL CONSIDERATIONS}

World reading made possible the increasingly critical deciphering of limit situations through dialogical exercise among students with respect to individual knowledge. From this experience, positive constructions were performed with those involved. Therefore, the interaction between young students brought contributions about cyberbullying, since the youths adopted reflective attitudes towards the public health problem. From this perspective, the communication produced was of paramount importance to answer the students' doubts about the subject, aiming at the dissemination of information based on the real needs presented by them.

\section{REFERENCES}

1. Abreu LDP, Torres RAM, Silva MRF, Araújo AF. Web radio como ferramenta de diálogo em saúde coletiva no sertão: juventudes e métodos contraceptivos. Sanare Sobral[Internet]. 2018 [cited 2019 Jan 5];17(1):24-31. Available from: https://sanare.emnuvens.com.br/sanare/article/ view/1219

2. Albuquerque IMN, Gomes DF, Vasconcelos AMM, Aguiar DT, Silva TB. Bullying na concepção de estudantes do ensino fundamental de uma escola pública. Rev Enferm UFSM. 2015;5(3):444-53. doi: 10.5902/2179769214795

3. Bottino SM, Bottino CMC, Regina CG, Correia AVL, Ribeiro WS. Cyberbullying and Adolescent Mental Health: systematic review. Cad Saúde Pública. 2015;31(3):463-75. doi: 10.1590/0102-311X00036114

4. Silva MAI. Bullying entre pares na escola: desafio aos enfermeiros que atuam na atenção básica à saúde. Rev Eletr Enf. 2013;15(3): 603-4. doi:10.5216/ree.v15i3.24527

5. Silva CRL, Carvalho V, Figueiredo NMA, Tonini T. Conceito de Cuidado/Conforto: Objeto de Trabalho e Objeto de Conhecimento de Enfermagem. Cogitare Enferm. 2011;16(2):357-60.

6. Silva MAI, Silva JL, Pereira BO, Oliveira WA, Medeiros M. The view of teachers on bullying and implications for nursing. Rev Esc Enferm USP. 2014;48(4):723-30. doi: 10.1590/S0080-623420140000400021

7. Abreu LDP, Mendonça GMM, Andrade AC, Oliveira GR, Aurélio DO, Rocha FAA, et al. Abordagem educativa utilizando os Círculos de Cultura de Paulo Freire: experiência de acadêmicos de enfermagem no "Grupo Adolescer". Adolesc. Saude [Internet]. 2013 [cited 2017 Feb 21]; 10(4): 66-70. Available from: http://www.adolescenciaesaude.com/detalhe_artigo.asp?id=427

8. Brandão CR. O que é o método Paulo Freire. 32a ed. São Paulo: Brasiliense; 2011. 
9. Silva FR, Assis SG. Prevenção da violência escolar: uma revisão da literatura. Educ Pesqui. 2018;44(1):01-13. doi: 10.1590/ s1517-9702201703157305

10. Torres RAM, Freitas GH, Vieira DVF, Torres ALMM, Silva LMS. Tecnologias digitais e educação em enfermagem: a utilização de uma web- rádio como estratégia pedagógica. J Health Inform [Internet]. 2012 [cited 2018 Apr 21];4(1):152-6. Available from: http://www.jhi-sbis.saude.ws/ ojs-jhi/index.php/jhi-sbis/article/view/248

11. Torre RAM, Silva MAM, Bezerra AEM, Abreu LDP, Mendonça GMM. Comunicação em saúde: uso de uma web rádio com escolares. J Health Inform [Internet]. 2015 [cited 2018 Abr 21]; 7(2): 58-61. Available from: http://www.jhi-sbis.saude.ws/ojs-jhi/index.php/jhi-sbis/article/ view/325

12. Minayo MCS. O desafio do conhecimento: pesquisa qualitativa em saúde. 13a ed. São Paulo: Hucitec; 2013.

13. Tomşa R, Jenaro C, Campbell M, Neacşu D. Student's experiences with traditional bullying and cyberbullying: findings from a romanian sample. Procedia Soc BehavSci. 2013;78:586-90. doi: 10.1016/j.sbspro.2013.04.356

14. Rondina JM, Moura JL, Carvalho MD. Cyberbullying: o complexo bullying da era digital. Rev Saúde Dig Tecnol Educ[Internet]. 2016 [cited 2018 Nov 21];1(1):20-41. Available from: http://www.periodicos.ufc.br/resdite/article/view/4682/3485

15. Perron T. Peer victimisation: strategies to decrease bullying in schools. Br J Sch Nurs. 2013;8(1):25-9. doi: 10.1590/0104-07072018000310017 